\title{
The Kolumbo submarine volcano of Santorini island is a large pool of bacterial strains with antimicrobial activity
}

\author{
Maria Bourbouli $\cdot$ Efstathios A. Katsifas • \\ Evangelos Papathanassiou • Amalia D. Karagouni
}

Received: 28 November 2014 / Revised: 13 January 2015 / Accepted: 16 January 2015

(C) Springer-Verlag Berlin Heidelberg 2015

\begin{abstract}
Microbes in hydrothermal vents with their unique secondary metabolism may represent an untapped potential source of new natural products. In this study, samples were collected from the hydrothermal field of Kolumbo submarine volcano in the Aegean Sea, in order to isolate bacteria with antimicrobial activity. Eight hundred and thirty-two aerobic heterotrophic bacteria were isolated and then differentiated through BOX-PCR analysis at the strain level into 230 genomic fingerprints, which were screened against 13 different type strains (pathogenic and nonpathogenic) of Gram-positive, Gram-negative bacteria and fungi. Forty-two out of 176 bioactive-producing genotypes $(76 \%)$ exhibited antimicrobial activity against at least four different type strains and were selected for $16 \mathrm{~S}$ rDNA sequencing and screening for nonribosomal peptide (NRPS) and polyketide (PKS) synthases genes. The isolates were assigned to genus Bacillus and Proteobacteria, and 20 strains harbored either NRPS, PKS type I or both genes. This is the first report on the diversity of culturable mesophilic bacteria associated with antimicrobial activity from Kolumbo area; the extremely high proportion of antimicrobial-producing strains suggested that this unique environment may represent a potential reservoir of novel bioactive compounds.
\end{abstract}

Communicated by Erko Stackebrandt.

M. Bourbouli · E. A. Katsifas · A. D. Karagouni $(\bowtie)$

Microbiology Laboratory, Department of Botany, Faculty

of Biology, National and Kapodistrian University of Athens,

15701 Athens, Greece

e-mail: akar@biol.uoa.gr

E. Papathanassiou

Institute of Oceanography, Hellenic Centre for Marine Research,

P.O. Box 712, 19013 Anavissos, Attiki, Greece
Keywords Kolumbo hydrothermal vents $\cdot$ Mesophiles · Bioactivity

\section{Introduction}

The increasing number of antibiotic multi-resistant bacterial pathogens makes urgent need for the discovery of new antibacterial agents. Since microbes have been revealed as an excellent source of new drugs and the majority of antibiotics used to date derive from molecular scaffolds of natural products or their semisynthetic derivatives (Newman and Cragg 2007), efforts for novel scaffold discovery are focused on the mining of largely unexplored microbial niches (Fischbach and Walsh 2009). It seems that the oceans are a prolific and (unlike the terrestrial environment) relatively unexploited source of novel natural products. Since the 1960s, many novel pharmaceutical compounds produced by a diverse range of marine bacteria have been isolated with antitumor, antiviral, antimicrobial or generally cytotoxic properties (Gerwick and Fenner 2013; Mayer et al. 2013). Therefore, marine microorganisms may represent an efficient and successful source for natural products research.

Deep-sea hydrothermal ecosystems, lying below 200-m depth (Tarasov et al. 2005), are colonized by dense communities living in complete darkness and surrounded by an almost desert sea bottom (Thornburg et al. 2010). They are considered to be a promising resource of novel chemotypes with medicinally relevant biological activities as they represent one of the most extreme and dynamic environments on Earth. The hot and reduced conditions at the vent outlets are replaced by cooler and more oxidized conditions at the outer chimney walls and sediment-seawater interface, with significant variations recorded in physical $(\mathrm{pH}$, temperature) and chemical parameters $\left(\mathrm{O}_{2}\right.$, nutrient and 
metal concentrations), which provide multiple ecological niches (Pettit 2011). The most abundant bacteria in vents are members of mesophilic communities adapted to life at temperatures near the ambient seawater (Prieur 2005) and capable of utilizing both vent-derived reductants and seawater-derived oxidants as nutrients (Olins et al. 2013). The adaptation strategies of vent microbial colonizers for survival against such fluctuating conditions induce genomic innovation (Sogin et al. 2006) and metabolic pathways with promising unique bioactivities (Skropeta 2008; Wilson and Brimble 2009).

So far, diverse deep-sea hydrothermal fields such as Okinawa Trough, East Pacific Rise and mid-Atlantic Ridge have been proved a new source of unique exopolysaccharides and unusual secondary metabolites with medical applications of bacterial origin (Blunt et al. 2014). The glycosaminoglycan-like polysaccharide produced by the bacterium Vibrio diabolicus exhibits effective results on the enhancement of bone regeneration in vivo while the novel secondary metabolites Ammonificins C 105 and D 106 isolated from a Thermovibrio ammonificans strain induce apoptosis in a cell-based screen (Senni et al. 2013). In addition, genes encoding for bioactive compounds of nonribosomal peptide synthetases and polyketide synthases type I (PKS-I) were detected from Actinobacteria isolates retrieved from Mariana Trench sediments (Pathom-aree et al. 2006).

The aim of the present study was to isolate mesophilic bacteria with potential antimicrobial activity from microbial mats of chimney and sediment samples retrieved from the active hydrothermal field of Kolumbo submarine volcano (500-m depth) about $7 \mathrm{~km}$ off the northeastern coast of Santorini, in the Aegean Sea. According to previous studies (Carey et al. 2011; Kilias et al. 2013), Kolumbo active chimneys were characterized by a permeable framework of sulfides and sulfates with vent plumes emitting mainly $\mathrm{CO}_{2}$ at $210{ }^{\circ} \mathrm{C}$ and seawater $\mathrm{pH}$ as low as 5.0, while the Fe-rich crater floor was mantled by white and reddish-orange microbial mats with temperature recorded between 16.2 and $17{ }^{\circ} \mathrm{C}$. To our knowledge, the present study is the first to survey the diversity of deep-sea hydrothermal vent bacteria that produce antimicrobial agents. The study was based on the isolation of bacteria according to their activity against pathogenic and nonpathogenic bacteria and fungi. In addition, attempts were made to identify specific genes, such as NRPS and PKS type I, known to be responsible for those bacterial responses.

\section{Materials and methods}

Samples collection

During E/V Nautilus 2010 expedition in the Aegean Sea (Carey et al. 2011), sediment and chimney samples were
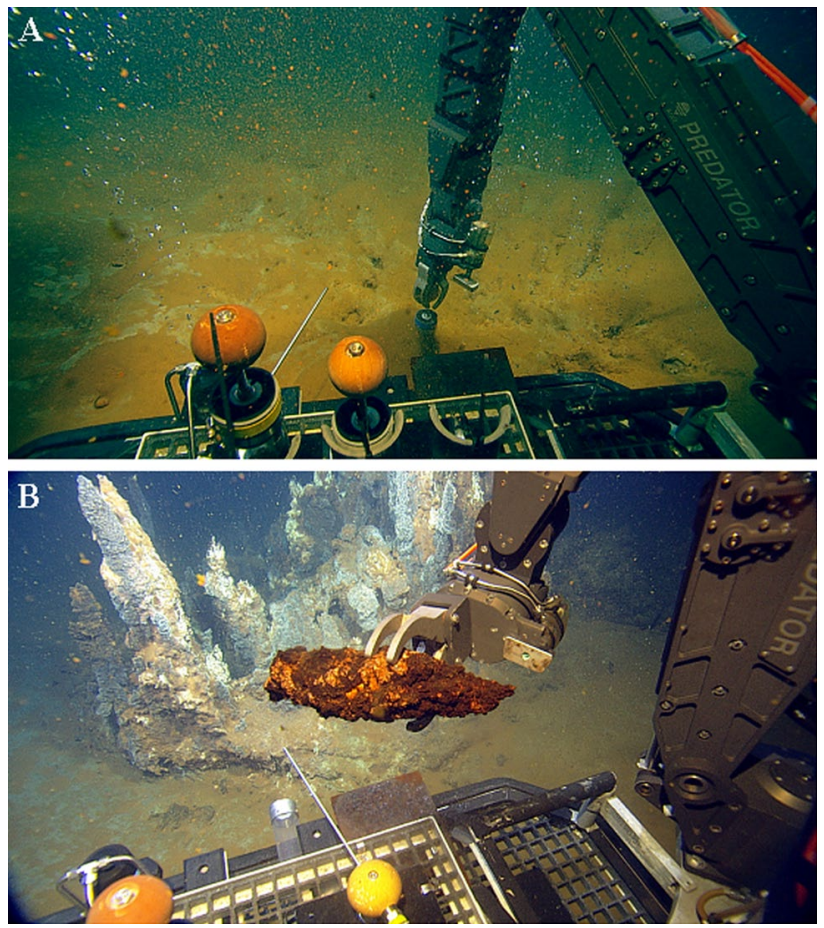

Fig. 1 a Sediment sampling by the ROV manipulator arm using a push core $(36: 31.5698 \mathrm{~N}$ and $25: 29.1432 \mathrm{E})$. b Sampling from the chimney by the ROV manipulator arm $(36: 31.5413 \mathrm{~N}$ and 25:28.5181E)

collected on Hercules ROV (Remote Operating Vehicle), Dive 1705 from the hydrothermal field in the north part of the crater of Kolumbo submarine volcano (500-m depth). The in situ temperature $\left(17^{\circ} \mathrm{C}\right)$ was determined using the external Hercules temperature probe. The sediment sample was collected by a push core (Core No. 12, Fig. 1a) (36:31.5698N and 25:29.1432E) and the chimney sample (36:31.5413N and $25: 28.5181 \mathrm{E})$ by the ROV manipulator arm (Fig. 1b). Once on board, the sediment sample was extracted with an autoclaved glass cylinder, while the surface of the chimney spires was scraped with a sterile scalpel and then loaded into sterile tubes (Falcon Type) of $50 \mathrm{~mL}$ volume. In both sediment and chimney samples, sterilized filtered seawater was added containing $0.05 \%$ $(w / v) \mathrm{Na}_{2} \mathrm{~S}$ before storage at $+4{ }^{\circ} \mathrm{C}$ until use.

\section{Isolation of the bacterial strains}

For the isolation of microorganisms, the samples were serially and decimally diluted from $10^{-1}$ to $10^{-7}$ with filtered sterile seawater as diluent. Aliquots $(100 \mu \mathrm{L})$ were subsequently spread onto agar plates with diverse media, $\mathrm{pH}$ adjusted to 7.2 before autoclaving and incubated aerobically up to 6 weeks at room temperature for the retrieval of heterotrophic mesophiles (Inagaki et al. 2003; Gontang 
et al. 2007). Three different media were used for isolation: (1) Marine Agar medium (2216 Difco, BD), (Joint et al. 2010), (2) tryptone-yeast extract-glucose agar (TYGA) (Kontro et al. 2005) modified by replacing yeast extract with $0.1 \% \mathrm{~K}_{2} \mathrm{HPO}_{4}, 0.05 \% \mathrm{MgSO}_{4} \cdot 7 \mathrm{H}_{2} \mathrm{O}, 0.001 \%$ $\mathrm{Fe}_{2}\left(\mathrm{SO}_{4}\right)_{3} \cdot 6 \mathrm{H}_{2} \mathrm{O}, \quad 0.0001 \% \quad \mathrm{CuSO}_{4} \cdot 5 \mathrm{H}_{2} \mathrm{O}, 0.0001 \%$ $\mathrm{ZnSO}_{4} \cdot 7 \mathrm{H}_{2} \mathrm{O}$ and $0.0001 \% \mathrm{MnSO}_{4} \cdot \mathrm{H}_{2} \mathrm{O}$ and (3) glycerolarginine agar medium (Kontro et al. 2005) modified as follows: $0.5 \%$ tryptone, $1.25 \%$ glycerol, $0.1 \% \mathrm{NaCl}, 0.1 \%$ $\mathrm{K}_{2} \mathrm{HPO}_{4}, 0.05 \% \mathrm{MgSO}_{4} \cdot 7 \mathrm{H}_{2} \mathrm{O}, 0.001 \% \mathrm{Fe}_{2}\left(\mathrm{SO}_{4}\right)_{3} \cdot 6 \mathrm{H}_{2} \mathrm{O}$, $0.0001 \% \quad \mathrm{CuSO}_{4} \cdot 5 \mathrm{H}_{2} \mathrm{O}, 0.0001 \% \mathrm{ZnSO}_{4} \cdot 7 \mathrm{H}_{2} \mathrm{O}$ and $0.0001 \% \mathrm{MnSO}_{4} \cdot \mathrm{H}_{2} \mathrm{O}$. Three agar plates were inoculated from each dilution and culture media. After incubation, plates were examined and colonies were selected and transferred to new agar plates several times for isolation and purification. The cultures were stored in $30 \%(\mathrm{w} / \mathrm{w})$ glycerol solutions at $-80{ }^{\circ} \mathrm{C}$.

DNA extraction and whole-genome bacterial fingerprinting (BOX-PCR)

Genomic DNA extraction was performed following the protocol of Moore et al. (2004). Electrophoresis of the DNA obtained was performed using $1 \%(\mathrm{w} / \mathrm{v})$ agarose gels (Agarose Basic, Applichem $\mathrm{GmbH}$ ). Genomic DNA was eluted from the spin column with $100 \mu \mathrm{L}$ of elution buffer for immediate use or storage at $-20^{\circ} \mathrm{C}$.

The BOX element (BOX1A) was amplified as described by Rademaker et al. (2004), using the BOXA1R primer 5'-CTACGGCAAGGCGACGCTGACG-3'. Amplification procedures were performed as follows: The samples were denatured at $95{ }^{\circ} \mathrm{C}$ for $10 \mathrm{~min}$, amplified in 30 cycles of $94{ }^{\circ} \mathrm{C}$ for $30 \mathrm{~s}, 52^{\circ} \mathrm{C}$ for $1 \mathrm{~min}, 65^{\circ} \mathrm{C}$ for $6.5 \mathrm{~min}$ followed by a final extension step of $65^{\circ} \mathrm{C}$ for $16 \mathrm{~min}$. The BOX products were electrophorized in a $1.5 \%(\mathrm{w} / \mathrm{v})$ agarose gel for $240 \mathrm{~m}$ at $110 \mathrm{~V}$ in $1 \mathrm{xTAE}$. The PCR for each isolate was repeated three times for reproducibility.

In vitro antimicrobial activity of the isolates corresponding to the different BOX genomic fingerprints

The antimicrobial activity was tested by diffusion method against indicator strains of Gram-positive bacteria [Bacillus subtilis (DSM 10), Micrococcus luteus (DSM 1790), Kocuria rhizophila (DSM 348), the pathogens Staphylococcus aureus (DSM 1104), Enterococcus faecalis (DSM 2570), Streptococcus pneumoniae (DSM 24048)], Gram-negative bacteria [Acinetobacter radioresistens (DSM 6976), Pseudomonas fluorescens (DSM 50090), the pathogens Neisseria gonorrhoeae (DSM 9189), Pseudomonas aeruginosa (DSM 1117), E. coli (DSM 1103)], the filamentous fungus Aspergillus niger (DSM 1957) and the pathogenic yeast Candida albicans (DSM 1386).
Aliquots $(10 \mu \mathrm{L})$ of overnight liquid cultures of isolates were plated onto seawater agar plates (Gontang et al. 2007) incubated for $96 \mathrm{~h}$ at $25^{\circ} \mathrm{C}$ and then overlaid by soft medium containing $0.7 \%$ sterilized soft agar (kept at $50{ }^{\circ} \mathrm{C}$ ) inoculated with overnight liquid culture of the indicator strain (exception: Asp. niger, 3 days culture). The following media were used for overlay: $0.8 \% \mathrm{NB}$ (Nutrient Broth, HiMedia M002) for B. subtilis, M. luteus, K. rhizophila and P. fluorescens, $0.24 \%$ PDB (Potato Dextrose Broth, DIFCO 254920) for A. niger, $0.21 \%$ YM (Yeast Mold, DIFCO 271120) for C. albicans, $0.3 \%$ TSB (Tryptone Soya Broth, Oxoid CM0131) for A. radioresistens and $0.21 \%$ ISTB (Iso SensiTest Broth, Oxoid CM047) for N. gonorrhoeae, S. aureus, Enterococcus faecalis, P. aeruginosa, S. pneumonia and E. coli. To allow the growth of the indicator strains, the overlaid plates were incubated for $24 \mathrm{~h}$ at $30{ }^{\circ} \mathrm{C}$ or $37{ }^{\circ} \mathrm{C}$ (for bacterial pathogens). After incubation, the plates were checked for growth inhibition zones. Experiments were carried out in triplicate, and similar results were obtained. The activity was considered to be weak if the inhibition zone was $\leq 1 \mathrm{~cm}$ wide.

Partial 16S rRNA gene sequencing of the isolates shown to have strong inhibitory activity

Amplification of the 16S rRNA gene was performed in $50 \mu \mathrm{L}$ reaction mix containing $50 \mathrm{ng}$ of extracted genomic DNA, $5 \mu \mathrm{L} 1 \times$ reaction buffer, $2.5 \mu \mathrm{L} 50 \mathrm{mM} \mathrm{MgCl}{ }_{2}$, $1 \mu \mathrm{L}$ dNTP Mix $10 \mathrm{mM}$ each, 20 pmol of each primer, $4 \%$ (v/v) DMSO, 5 unit Taq DNA polymerase (Biotools, England). Nuclease-free water was used to bring the reaction volume to $50 \mu \mathrm{L}$. The $16 \mathrm{~S}$ rRNA gene primers used were pA 5'-AGAGTTTGATCCTGGCTCAG-3' and R1492 5'-TACGGYTACCTTGTTACGACT-3' (Devereux and Wilkinson 2004). The PCR conditions were $95{ }^{\circ} \mathrm{C}$ for $3 \mathrm{~min}$, then 35 cycles each of $30 \mathrm{~s}$ at $94{ }^{\circ} \mathrm{C}, 1 \mathrm{~min}$ at $56{ }^{\circ} \mathrm{C}$ and $1.5 \mathrm{~min}$ at $72{ }^{\circ} \mathrm{C}$. A final extension step of $72{ }^{\circ} \mathrm{C}$ for 5 min was then performed. The amplified 16S rRNA gene fragments were analyzed on $1.2 \%(\mathrm{w} / \mathrm{v})$ agarose gel, purified with Nucleospin Extract PCR kit (Macherey-Nagel, Germany) and used as sequencing templates. Sequencing was carried out by VBC-BIOTECH Service GmbH (Austria) using R1492 primer. Homology searches were performed, and close relatives were determined in the GeneBank database using the nucleotide BLAST with default parameters within National Center for Biotechnology Information (NCBI). The sequences were aligned against reference sequences by MUSCLE, and the aligned dataset was used as input for phylogenetic analysis performed with program Molecular Evolutionary Genetics Analysis (MEGA), version 6.0 (Tamura et al. 2013). Tree topology was evaluated by bootstrap analyses based on 1,000 replicates, and 
the phylogenetic tree was inferred using the neighborjoining method. The obtained 16S rRNA gene sequences were deposited in the EMBL Nucleotide Sequence Database (http://www.ebi.ac.uk/ena/) under Accession Numbers HG764607-HG764648.

Screening of the most active isolates for nonribosomal peptide synthetase (NRPS) and polyketide synthase type I (PKS) genes

For the PKS and NRPS genes screening, gene fragments of the most conserved domains (ketosynthase KS domain of PKS and adenylation A domain of NRPS) were amplified as recommended by Zhang et al. 2008, 2009, using the following degenerate oligonucleotide primers: for KS domain, GBf (5'-RTRGAYCCNCAGCAICG-3')-GBr (5'-VGTNCCNGTGCCRTG-3'), GCf (5'-GCSATGGAYCCSCARCARCGSVT-3')-GCr (5'-GTSCCSGTSCCRTG SSCYTC SAC- $\left.3^{\prime}\right)$, KSDPQQf ( $5^{\prime}$-MGNGARGCNNWN SMNATGGAYCCNCARCANMG-3')-KSHGTGr ( $5^{\prime}$ - GGRTCNCCNAR N S W NGT NCCNGTNCCRTG-3'). For A domain, MTF (5'-GCNGGYGGYGCNTAYGTNCC-3')-MTR (5'-CCNCGDATYTTNACY TG-3'), NS1 (5'-CAACCCCTATGCCTTTTGAA-3') - NS2 (5'-TAAACAACCCATGCTCCACA-3'), NP1 (5'-CCTA ATTCAATACGAAAACCACGAADYTTNAYYTG- $3^{\prime}$ )NP2 (5'-TGTATGTTATTTATACTTCTGGTTCTACTGGTMRNCCANARG G-3'). A reaction volume of $50 \mu \mathrm{L}$ contained $5 \mu \mathrm{L}$ of $1 \times$ reaction buffer, $2 \mu \mathrm{L}$ of $\mathrm{MgCl}_{2}$ $50 \mathrm{mM}, 5 \mu \mathrm{L}$ DMSO $100 \%, 1 \mu \mathrm{L}$ dNTPs Mix $10 \mathrm{mM}$ each, $2 \mu \mathrm{L}$ of each primer $100 \mathrm{mM}, 0.25 \mu \mathrm{L}$ of unit Taq DNA polymerase (Biotools, Spain) and 1 or $2 \mu \mathrm{L}(50$ $100 \mathrm{ng}$ ) of template DNA. Amplification cycles consisted of an initial denaturation step of $94^{\circ} \mathrm{C}$ for $5 \mathrm{~min}, 35$ cycles of $94{ }^{\circ} \mathrm{C}$ for $1 \mathrm{~min}, 50{ }^{\circ} \mathrm{C}$ for PKS and $55{ }^{\circ} \mathrm{C}$ for NRPS for $1 \mathrm{~min}, 72{ }^{\circ} \mathrm{C}$ for $2 \mathrm{~min}$ for amplification and a final extension step of $72{ }^{\circ} \mathrm{C}$ for $10 \mathrm{~min}$. The amplicons were visualized, and the ones of the correct size $(1,000$ and 700 bp for NRPS and PKS genes, respectively) were gel purified (Nucleospin Extract PCR kit, Macherey-Nagel, Germany) and cloned into pTZ57R/T vectors (Fermentas, USA). Sequencing of the cloned inserts was carried out by VBC-BIOTECH Service GmbH (Austria) using M13/pUC F (5'-GTTTTCCCAGTCACGAC-3') primer. The deduced amino acid sequences of $\mathrm{A}$ and KS domains were used as queries to search related proteins in the $\mathrm{nr}$ protein database at NCBI using the BlastP algorithm with default parameters. Phylogenetic trees based on the 19 amino acid sequences of $\mathrm{A}$ domains and the six amino acid sequences of KS domains were constructed using the multiple sequence alignment tools in MUSCLE and mega package. Neighbor-joining method was adopted with 1,000 bootstrap reiterations. The gene sequences were deposited in GenBank under the Accession Numbers KM186546-KM186570.

\section{Results}

Diversity of mesophilic bacteria in the Kolumbo hydrothermal field

Eight hundred and thirty-two mesophilic heterotrophic bacteria were recovered using three different culture media. Six hundred and forty-four strains were isolated from the sediment sample, $34 \%$ of which were isolated using marine agar medium and the rest $(66 \%)$ from modified TYGA medium. One hundred and eighty-eight strains were isolated from the chimney sample; $50 \%$ of the isolates derived from the marine agar medium, $19 \%$ from the modified TYGA medium and $31 \%$ from the modified glycerolarginine agar medium. Whole-genome genotyping using the BOX-PCR methodology was performed, and differentiation of all isolated bacteria based on their BOX-PCR genomic fingerprints revealed 230 distinct genotypes, 38 of which derived from the chimney sample. The representatives of the different genomic fingerprints detected were principally present up to eight times, forming a variety of small different genotypic groups, except six major groups containing from 20 to 47 isolates.

Antimicrobial activity of the isolated strains

One hundred and seventy-six out of the 230 different genotypes showed antimicrobial activity against at least one of the 13 indicator strains. Fifty-four of the active isolates were active only against Gram-positive bacteria, three isolates exhibited activity only against Gram-negative bacteria and 13 isolates were active only against fungi. Twentysix isolates inhibited the growth of both Gram-positive and Gram-negative bacteria, 39 isolates exhibited activity against both Gram-positive bacteria and fungi, five isolates were active against both Gram-negative bacteria and fungi and 36 strains were active against Gram-positive and Gram-negative bacteria and fungi. The most frequently inhibited targets were the Gram-positive pathogens S. pneumonia, S. aureus and the fungus A. niger. $21.6 \%$ of the isolates tested inhibited the growth of the yeast test strain, C. albicans.

Taxonomy of the most bioactive isolated strains by $16 \mathrm{~S}$ rDNA analysis

Forty-two of the isolates, deriving from both chimney and sediment samples, exhibited strong antimicrobial activity after the repeated transfer to new media (Table 1) and were 
Arch Microbial

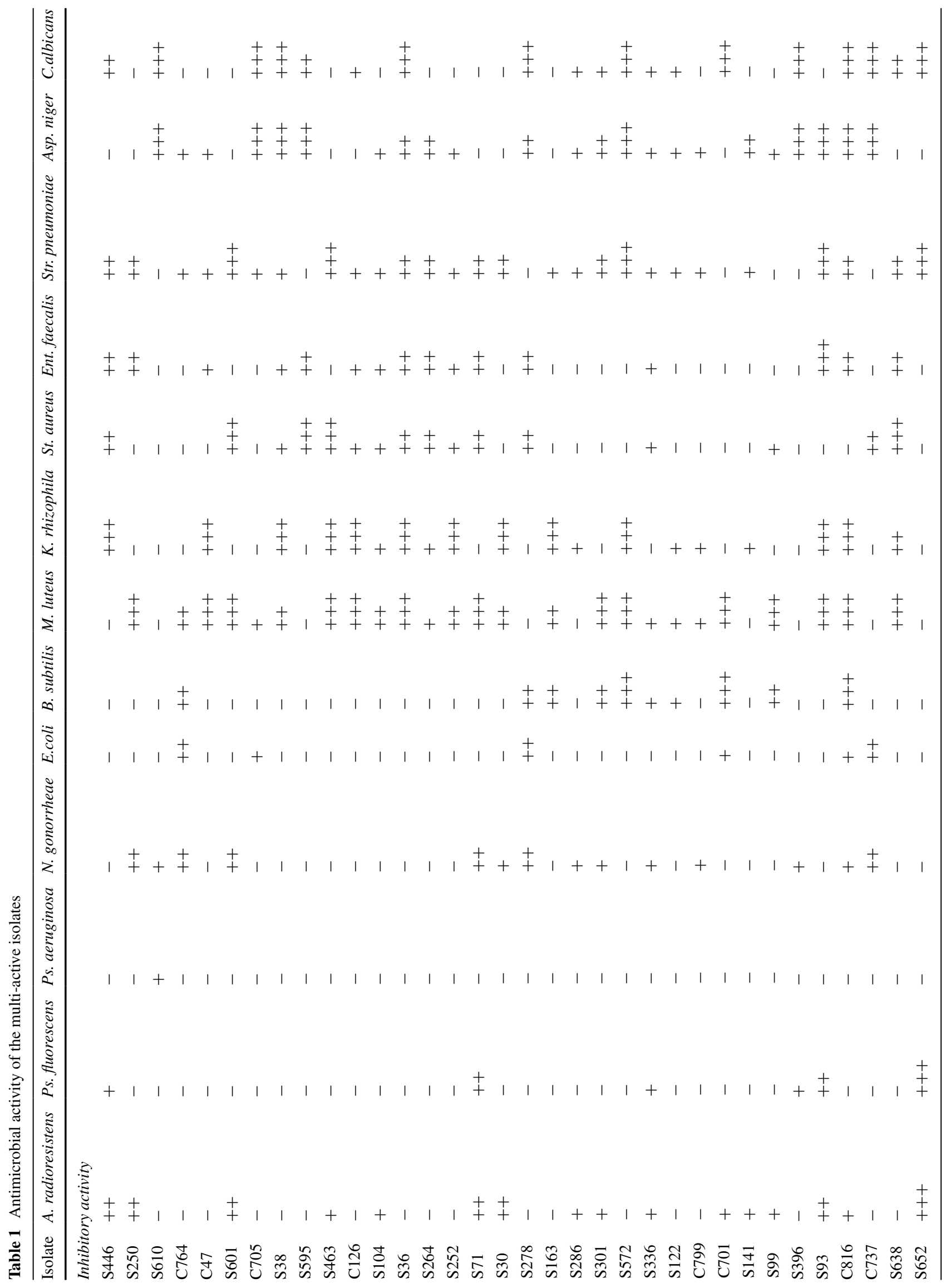

Springer 


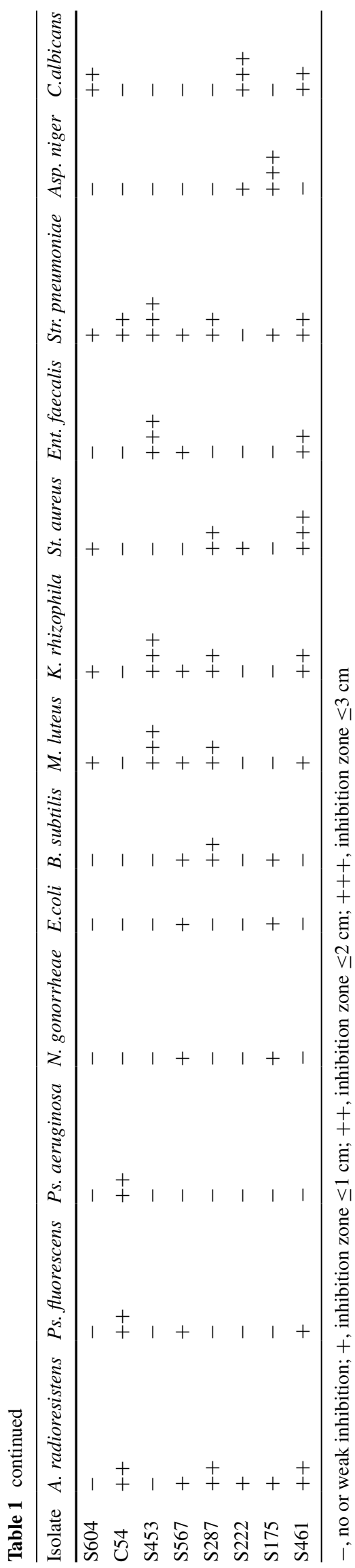

chosen for sequencing and phylogenetic analysis (Table 2). They were submitted to partial $16 \mathrm{~S}$ rDNA analysis, followed by BLAST search of GenBank database and phylogenetic tree calculation by using the neighbor-joining algorithm. Isolate $16 \mathrm{~S}$ rRNA gene sequences were grouped into two distinct clusters (Fig. 2). Eleven different 16S rRNA gene OTUs were found, seven of which were identified at the genus level as Bacillus (98-100\% identity) and comprised 35 isolates derived from sediment and chimney samples. Three OTUs were assigned to the $\gamma$-Proteobacteria, genera Pseudomonas and Halomonas (97-99.9 \% identity) corresponding to six strains, isolated from the sediment sample and one OTU was affiliated with a strain isolated from the chimney sample, belonging to $\alpha$-Proteobacteria, genus Loktanella (99.3\% identity).

Abundance of NRPS and PKS genes of the most bioactive isolates

In the present study, sequences of PKS type I and NRPS genes were obtained from 6 and 19 isolates, respectively; the rest of the multi-active strains tested, either may not contain these genes, or the genes were not amplified by the primers used. For phylogenetic analysis of PKS genes, reference strains were selected from NRPS-PKS, trans-acyl transferase (trans-AT) PKS, cis-acyl transferase (cis-AT) PKS and FAS (fatty acid synthase) families, and representatives of type II PKS were included as out-groups. Two KS domain sequences were related to hybrid NRPS-PKS genes, and four were grouped into the trans-acyltransferase (AT) type I polyketide synthases (Fig. 3), and interestingly, all of them showed a close relationship with reported Actinomycetales and Bacillus PKS genes of marine origin (Table 2).

Three Pseudomonas isolates showed high similarity to Pseudomonas NRPS-related genes and the rest (1 Pseudomonas and 15 Bacillus) of the isolates matched with NRPS genes isolated from Bacillus spp. (Table 2). The translated sequences showed similarities of 84-100\% to previously described NRPS adenylation domains and $87-100 \%$ to PKS ketosynthase protein domains. All of the deduced NRPS A domain amino acid sequences exhibited high similarity to nonribosomal peptide synthetase subunits with relatives involved in the biosynthesis of tyrocidine (TycC), bacitracin (BacA) and linear gramicidin $(\mathrm{LgrD})$ clustered with the saframycin A-like synthases, while the potent biosurfactant lichenysin (LchAA) clustered into the surfactin domain (SrfA-C)-like group. The latter group contained the majority of the A domains recovered as shown from phylogenetic analysis using reference strains of known NRPS genes including surfactin (SrfA-C) and saframycin (Sfm-A)-like A domain families (Fig. 4). 
Table 2 Similarity of $16 \mathrm{~S}$ rDNA sequences, NRPS adenylation and PKS $\beta$-ketosynthase domain amino acid sequences to their relatives in GenBank

\begin{tabular}{|c|c|c|c|c|c|c|c|c|c|}
\hline Strain & $\begin{array}{l}16 \mathrm{~S} \text { rDNA } \\
\text { accession no. }\end{array}$ & $\begin{array}{l}\text { Closest relative } \\
\text { (accession no.) }\end{array}$ & $\begin{array}{l}\text { Identity } \\
(\%)\end{array}$ & $\begin{array}{l}\text { NRPS gene } \\
\text { accession no. }\end{array}$ & $\begin{array}{l}\text { Closest relative } \\
\text { (accession no.) }\end{array}$ & Identity (\%) & $\begin{array}{l}\text { PKS gene } \\
\text { accession no. }\end{array}$ & $\begin{array}{l}\text { Closest relative } \\
\text { (accession no.) }\end{array}$ & $\begin{array}{l}\text { Identity } \\
(\%)\end{array}$ \\
\hline C54 & HG764612 & $\begin{array}{l}\text { L. hongkongensis } \\
\text { NR_029121.1 }\end{array}$ & 99.3 & & & & & & \\
\hline S453 & HG764633 & $\begin{array}{l}\text { H. sulphidaeris } \\
\text { NR_027185.1 }\end{array}$ & 99.9 & & & & & & \\
\hline S222 & HG764622 & $\begin{array}{l}\text { Ps.phychrotolerans } \\
\text { NR_042191.1 }\end{array}$ & 99.8 & & & & & & \\
\hline S287 & HG764628 & $\begin{array}{l}\text { Ps. moraviensis } \\
\text { NR_043314.1 }\end{array}$ & 97 & KM186546 & $\begin{array}{l}\text { LchAA } \\
\text { B.licheniformis } \\
\text { U95370.1 }\end{array}$ & 99 & & & \\
\hline S567 & HG764636 & $\begin{array}{r}\text { Ps. moraviensis } \\
\text { NR_043314.1 }\end{array}$ & 99.7 & KM186559 & $\begin{array}{l}\text { Ps.moraviensis } \\
\text { WP024012355.1 }\end{array}$ & 96 & & & \\
\hline S175 & HG764621 & $\begin{array}{r}\text { Ps. moraviensis } \\
\text { NR_074599.1 }\end{array}$ & 99.5 & KM186564 & $\begin{array}{l}\text { LgrD Ps. protegens } \\
\text { WP01563425.1 }\end{array}$ & 99 & & & \\
\hline S461 & HG764634 & $\begin{array}{r}\text { Ps. moraviensis } \\
\text { NR_074599.1 }\end{array}$ & 99.6 & KM186563 & $\begin{array}{l}\text { LgrD Ps. protegens } \\
\text { WP01563425.1 }\end{array}$ & 100 & & & \\
\hline S572 & HG764637 & $\begin{array}{l}\text { B. licheniformis } \\
\text { NR_074923.1 }\end{array}$ & 99.9 & KM186555 & $\begin{array}{l}\text { BacA B. } \\
\quad \text { licheniformis } \\
\text { WP020452079.1 }\end{array}$ & 98 & & & \\
\hline S336 & HG764630 & $\begin{array}{r}\text { B. licheniformis } \\
\text { NR_074923.1 }\end{array}$ & 99.8 & KM186556 & $\begin{array}{c}\text { BacA B. subtilis } \\
\text { ABB80123.1 }\end{array}$ & 98 & & & \\
\hline S122 & HG764617 & $\begin{array}{r}\text { B. licheniformis } \\
\text { NR_074923.1 }\end{array}$ & 99.8 & KM186547 & $\begin{array}{l}\text { TycIII B. sonorensis } \\
\text { WP006640279.1 }\end{array}$ & 99 & & & \\
\hline C799 & HG764648 & $\begin{array}{l}\text { B. megaterium } \\
\text { NR_074290.1 }\end{array}$ & 99.5 & & & & & & \\
\hline C701 & HG764644 & $\begin{array}{l}\text { B. safensis } \\
\quad \text { NR_041794.1 }\end{array}$ & 100 & KM186551 & $\begin{array}{l}\text { B. pumilus } \\
\text { WP025092822.1 }\end{array}$ & 95 & KM186569 & $\begin{array}{l}\text { B. subtilis } \\
\text { ABR19764.1 }\end{array}$ & 99 \\
\hline S141 & HG764619 & $\begin{array}{l}\text { B. safensis } \\
\quad \text { NR_041794.1 }\end{array}$ & 99.9 & KM186548 & $\begin{array}{l}\text { B. safensis } \\
\text { WP024424295.1 }\end{array}$ & 98 & & & \\
\hline S99 & HG764615 & $\begin{array}{l}\text { B. safensis } \\
\quad \text { NR_041794.1 }\end{array}$ & 99.9 & KM186557 & $\begin{array}{l}\text { B. pumilus } \\
\text { WP025092819.1 }\end{array}$ & 97 & & & \\
\hline S396 & HG764631 & $\begin{array}{l}\text { B. safensis } \\
\quad \text { NR_041794.1 }\end{array}$ & 99.9 & KM186554 & $\begin{array}{l}\text { B. pumilus } \\
\text { KDE51553.1 }\end{array}$ & 96 & & & \\
\hline S93 & HG764614 & $\begin{array}{r}\text { Br. halotolerans } \\
\text { NR_042638.1 }\end{array}$ & 99.8 & KM186552 & $\begin{array}{l}\text { B. subtilis } \\
\quad \text { WP015252053.1 }\end{array}$ & 84 & KM186567 & $\begin{array}{l}\text { Bacillus sp. } \\
\quad \text { WPhG3 } \\
\text { ACG70843.1 }\end{array}$ & 96 \\
\hline C816 & HG764643 & $\begin{array}{l}\text { B. subtilis } \\
\quad \text { NR_075005.1 }\end{array}$ & 100 & KM186562 & $\begin{array}{l}\text { B. amyloliquefa- } \\
\text { ciens } \text { EYB38008.1 }\end{array}$ & $1^{90}$ & KM186570 & $\begin{array}{l}\text { B.amylolique- } \\
\text { faciens } \\
\text { AGL92433.1 }\end{array}$ & 87 \\
\hline C737 & HG764646 & $\begin{array}{l}\text { B. subtilis } \\
\quad \text { NR_075005.1 }\end{array}$ & 99.9 & KM186560 & $\begin{array}{l}\text { B. subtilis } \\
\text { WP029946301.1 }\end{array}$ & 99 & & & \\
\hline S638 & HG764642 & $\begin{array}{l}\text { B. subtilis } \\
\quad \text { NR_075005.1 }\end{array}$ & 100 & KM186553 & $\begin{array}{l}\text { B. pumilus } \\
\text { KDE51551.1 }\end{array}$ & 97 & KM186566 & $\begin{array}{c}\text { Actinomycetales } \\
\text { ABR19779.1 }\end{array}$ & 97 \\
\hline S652 & HG764607 & $\begin{array}{l}\text { B. subtilis } \\
\text { NR_075005.1 }\end{array}$ & 99.7 & KM186561 & $\begin{array}{l}\text { B. subtilis } \\
\text { EXF52074.1 }\end{array}$ & 100 & & & \\
\hline S604 & HG764640 & $\begin{array}{l}\text { B. halmapalus } \\
\text { NR_026144.1 }\end{array}$ & 99.5 & & & & & & \\
\hline S446 & HG764632 & $\begin{array}{l}\text { B. pumilus } \\
\text { NR_043242.1 }\end{array}$ & 99.8 & KM186549 & $\begin{array}{l}\text { B. pumilus } \\
\text { KDE51553.1 }\end{array}$ & 98 & & & \\
\hline S250 & HG764623 & $\begin{array}{l}\text { B. pumilus } \\
\text { NR_043242.1 }\end{array}$ & 99.8 & & & & & & \\
\hline S610 & HG764641 & $\begin{array}{l}\text { B. pumilus } \\
\text { NR_043242.1 }\end{array}$ & 100 & & & & & & \\
\hline C764 & HG764647 & $\begin{array}{l}\text { B. pumilus } \\
\text { NR_043242.1 }\end{array}$ & 99.8 & KM186558 & $\begin{array}{l}\text { B. pumilus } \\
\text { KDE51553.1 }\end{array}$ & 97 & KM186565 & $\begin{array}{l}\text { B. subtilis } \\
\text { ABR19764.1 }\end{array}$ & 99 \\
\hline $\mathrm{C} 47$ & HG764611 & $\begin{array}{l}\text { B. pumilus } \\
\text { NR_043242.1 }\end{array}$ & 100 & & & & & & \\
\hline
\end{tabular}


Table 2 continued

\begin{tabular}{|c|c|c|c|c|c|c|c|c|c|}
\hline Strain & $\begin{array}{l}\text { 16S rDNA } \\
\text { accession no. }\end{array}$ & $\begin{array}{l}\text { Closest relative } \\
\text { (accession no.) }\end{array}$ & $\begin{array}{l}\text { Identity } \\
(\%)\end{array}$ & $\begin{array}{l}\text { NRPS gene } \\
\text { accession no. }\end{array}$ & $\begin{array}{l}\text { Closest relative } \\
\text { (accession no.) }\end{array}$ & Identity (\%) & $\begin{array}{l}\text { PKS gene } \\
\text { accession no. }\end{array}$ & $\begin{array}{l}\text { Closest relative } \\
\text { (accession no.) }\end{array}$ & $\begin{array}{l}\text { Identity } \\
(\%)\end{array}$ \\
\hline S601 & HG764639 & $\begin{array}{l}\text { B. pumilus } \\
\quad \text { NR_043242.1 }\end{array}$ & 100 & KM186550 & $\begin{array}{l}\text { B. pumilus } \\
\text { KDE51553.1 }\end{array}$ & 98 & & & \\
\hline S163 & HG764620 & $\begin{array}{l}\text { B. pumilus } \\
\quad \text { NR_043242.1 }\end{array}$ & 99 & & & & & & \\
\hline S286 & HG764627 & $\begin{array}{l}\text { B. pumilus } \\
\quad \text { NR_043242.1 }\end{array}$ & 98 & & & & & & \\
\hline S301 & HG764629 & $\begin{array}{l}\text { B. pumilus } \\
\quad \text { NR_043242.1 }\end{array}$ & 98 & & & & & & \\
\hline C705 & HG764645 & $\begin{array}{l}\text { B. pumilus } \\
\text { NR_043242.1 }\end{array}$ & 100 & & & & KM186568 & $\begin{array}{c}\text { Actinomycetales } \\
\text { ABR19779.1 }\end{array}$ & 97 \\
\hline S38 & HG764610 & $\begin{array}{l}\text { B. pumilus } \\
\text { NR_043242.1 }\end{array}$ & 100 & & & & & & \\
\hline S595 & HG764638 & $\begin{array}{l}\text { B. pumilus } \\
\text { NR_043242.1 }\end{array}$ & 99.9 & & & & & & \\
\hline S463 & HG764635 & $\begin{array}{l}\text { B. pumilus } \\
\text { NR_043242.1 }\end{array}$ & 100 & & & & & & \\
\hline C126 & HG764618 & $\begin{array}{l}\text { B. pumilus } \\
\quad \text { NR_043242.1 }\end{array}$ & 99.9 & & & & & & \\
\hline S104 & HG764616 & $\begin{array}{l}\text { B. pumilus } \\
\text { NR_043242.1 }\end{array}$ & 99.9 & & & & & & \\
\hline S36 & HG764609 & $\begin{array}{l}\text { B. pumilus } \\
\text { NR_043242.1 }\end{array}$ & 99.9 & & & & & & \\
\hline S264 & HG764625 & $\begin{array}{l}\text { B. pumilus } \\
\quad \text { NR_043242.1 }\end{array}$ & 99.9 & & & & & & \\
\hline S252 & HG764624 & $\begin{array}{l}\text { B. pumilus } \\
\quad \text { NR_043242.1 }\end{array}$ & 99.8 & & & & & & \\
\hline S71 & HG764613 & $\begin{array}{l}\text { B. pumilus } \\
\quad \text { NR_043242.1 }\end{array}$ & 99.8 & & & & & & \\
\hline S30 & HG764608 & $\begin{array}{l}\text { B. pumilus } \\
\quad \text { NR_043242.1 }\end{array}$ & 99.8 & & & & & & \\
\hline S278 & HG764626 & $\begin{array}{l}\text { B. pumilus } \\
\quad \text { NR_043242.1 }\end{array}$ & 99.8 & & & & & & \\
\hline
\end{tabular}

\section{Discussion}

According to previous studies, Kolumbo hydrothermal vent field was characterized by an atypical geodynamic setting with unique features among seafloor hydrothermal deposits. From small pockmark-like craters in the Fe-rich sediment and chimney spire outlets, $\mathrm{CO}_{2}$ gas bubbles were discharged (Kilias et al. 2013), suggesting that carbon fixation under such $\mathrm{CO}_{2}$-rich conditions is operated by vent mesophiles inhabiting the niches between reducing hydrothermal vents and toxic peripheral zones (Van Dover et al. 2002). The culture-based analysis of Kolumbo-associated mesophilic bacterial community revealed a rich mesophilic community, in contrast with previous culture-dependent studies of other deep-sea ecosystems (Kaye and Baross 2000; Gärtner et al. 2011; Castro da Silva et al. 2013). Whole-genome genotyping revealed that there were few major groups of similar fingerprints, implying high diversification at the strain level. The representatives of the most dominant genotypes showed no or weak antimicrobial activity. Phylogenetic analysis of the multi-active isolates indicated that the majority was affiliated with the phylum Firmicutes while previously, culture-independent studies revealed Proteobacteria as the dominant members of the bacterial mesophilic community (Kilias et al. 2013).

The results of the antimicrobial screening assays demonstrated an intense and broad metabolic activity by most of the isolates. Comparison with the proportion of bioactivityproducing bacteria isolated from other habitats like freeliving planktonic communities (Zheng et al. 2005), sponges (Penesyan et al. 2009) and marine sediments (Nithya and Pandian 2010) highlighted an extremely high percentage of active isolates $(76 \%)$ from sediment and chimney microbial mats against bacterial and eukaryotic (filamentous fungi and yeasts) indicator strains. This finding may be connected to the formation of microbial aggregations in surface-attached biofilms that offer protection to microorganisms, but also represent a highly competitive environment in terms of space and nutrients. The production of antimicrobial metabolites may serve to maintain a stable 


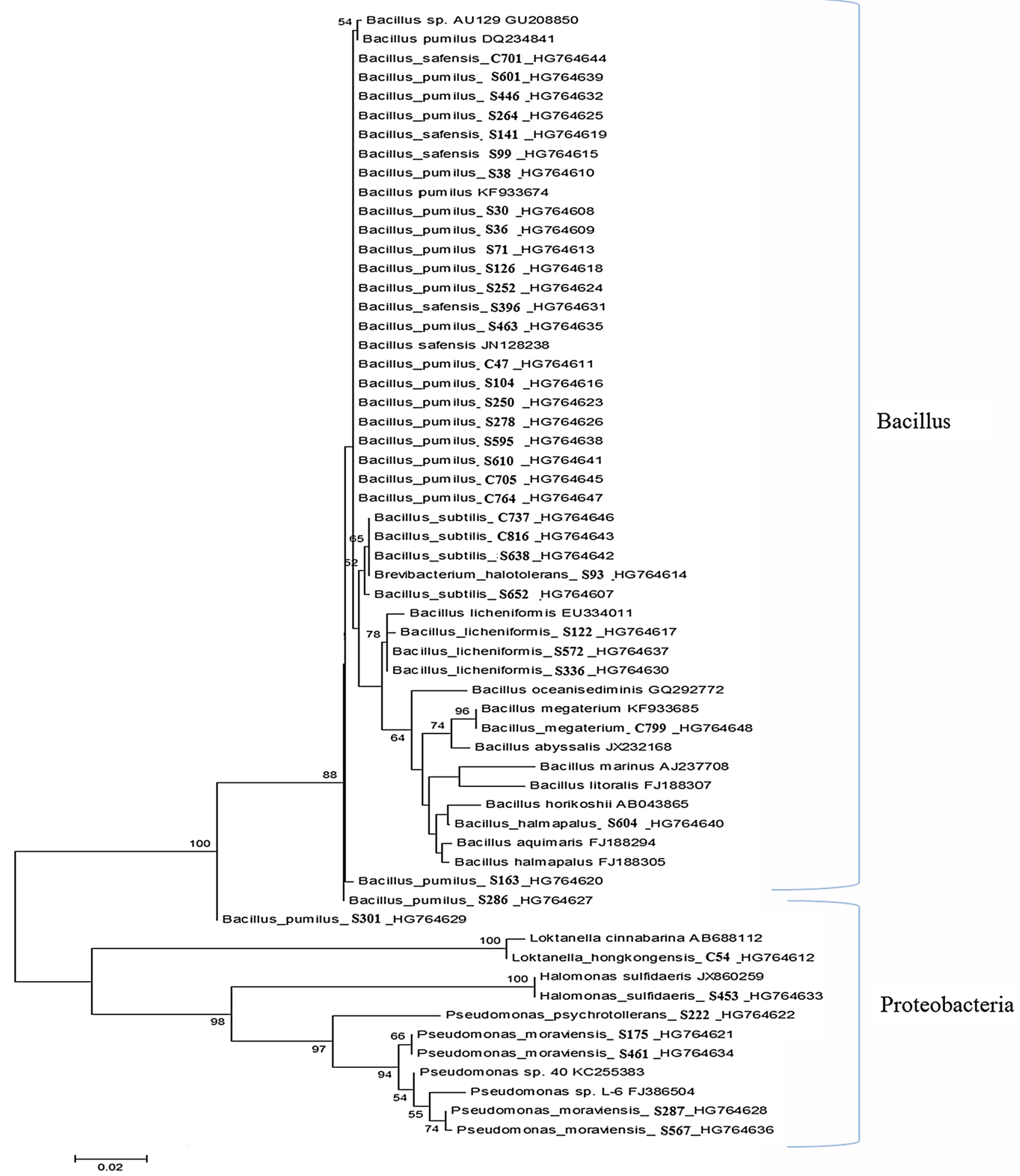

Fig. 2 Neighbor-joining phylogenetic tree based on the aligned partial 16S rRNA gene sequences (c. 700 nucleotide positions) of the antimicrobial strains and close relatives isolated from marine sediments. Sequences from the present study are highlighted in bold type
( $\mathrm{S}$ for sediment and $\mathrm{C}$ for chimney isolates). Percentage bootstrap values (1,000 resamplings) are given for major nodes. The scale bar indicates the number of substitutions per nucleotide position 

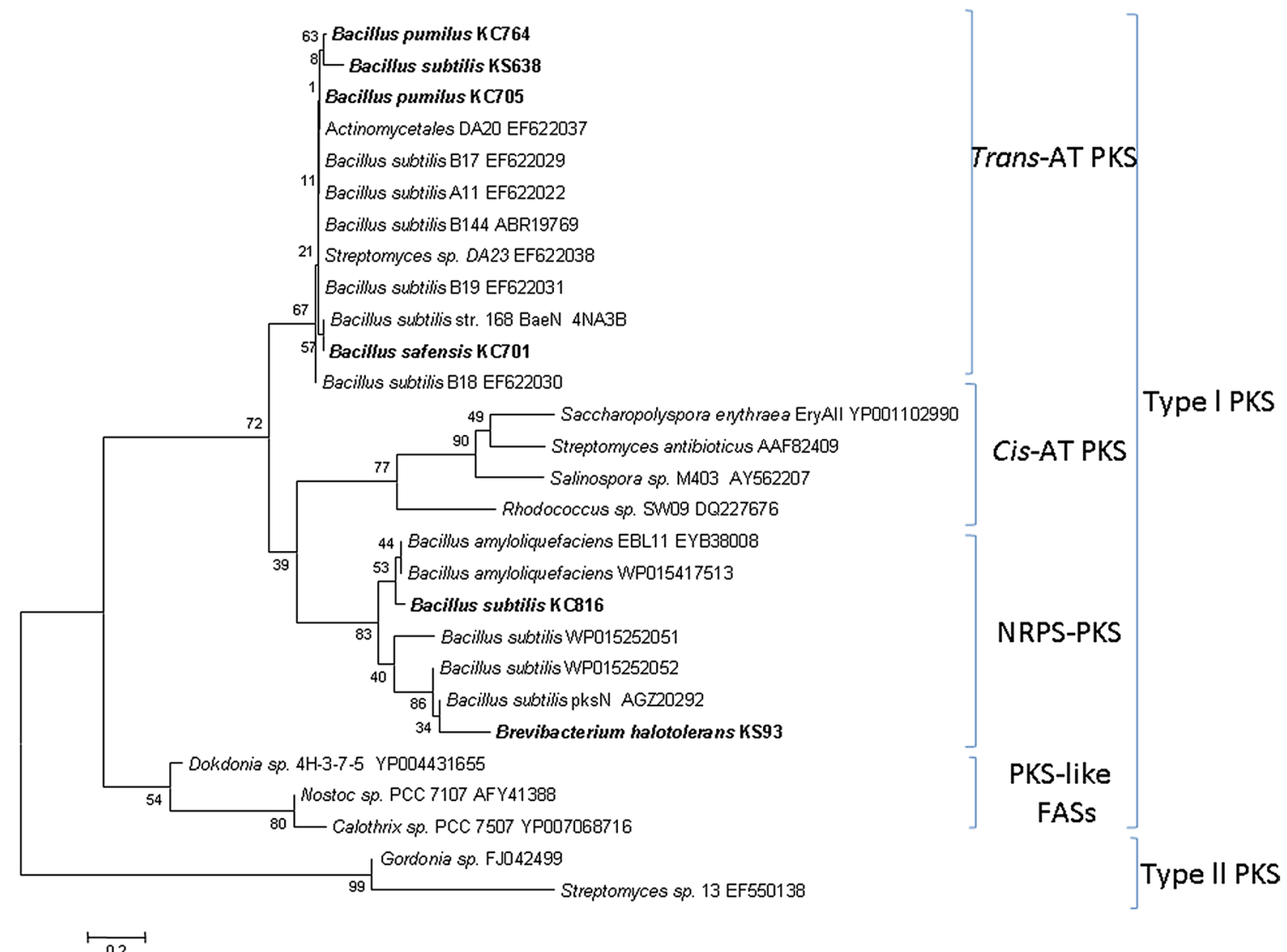

Fig. 3 Neighbor-joining phylogenetic tree of KS domain aa sequences of Kolumbo most bioactive isolates (highlighted in bold type with $\mathrm{KS}$ for sediment and $\mathrm{KC}$ for chimney isolates) and reference sequences including NRPS-PKS, trans-acyl transferase (trans-AT) PKS, cis-acyl transferase (cis-AT) PKS, FAS (fatty acid synthase) families. Representatives of type II PKS were added as out-groups. Percentage bootstrap values of neighbor-joining analysis from 1,000 resamplings are indicated at the nodes. The scale bar represents 0.2 amino acid substitutions per site composition of biofilm communities (Penesyan et al. 2010) and provide chemical defense against eukaryotic colonizers or predators (Matz et al. 2008). Moreover, the detection of high bioactivity against bacterial and fungal pathogens is significant given the increasing occurrence of multidrug resistant human pathogens and the necessity for novel antibiotics.

Forty-two isolates with strong antimicrobial activity were chosen for phylogenetic analysis. Although it is known that in the absence of bacterial interactions, the loss of certain metabolic capabilities due to a loss of plasmids or the lack of trigger substances or stress factors is frequently observed (Laatsch 2006), the selected isolates from Kolumbo under laboratory conditions exhibited strong activity even after repeated transfer to fresh media. That result suggested that those isolates may be amenable to large-scale production of antimicrobial agents.

Thirty-five out of the forty-two multi-active strains belonged to the genus Bacillus; marine sediments are the primary oceanic habitats from which Bacillus strains have been recovered (Austin 1988). In particular, B. pumilus and $B$. subtilis spp. are found to be the most abundant surface associated bacilli isolated from marine environment (Liu et al. 2013). Strains of Bacillus sp. isolated from the shallow hydrothermal field of D. João de Castro Seamount (DJCS) Azores (Mohandass et al. 2012) and Guaymas Basin, Gulf of California at 1,500-m depth (Dick et al. 2006), were studied for their adaptation strategies and their extended survival in toxic conditions. Their sporulation mechanism is correlated with antibiotic synthesis (Fickers 2012), which seems to be involved in quorum-sensing, biofilm and swarming development besides the antimicrobial action (Stein 2005). Seven isolates were included in the classes of $\alpha$ - and $\gamma$-Proteobacteria. Strain C54 is affiliated with the genus Loktanella of the Roseobacter clade: the only clade containing culturable members of the $\alpha$-Proteobacteria, which comprises one of the largest fractions of heterotrophic bacteria in the marine environment (Cottrell and Kirchman 2000). Previous studies on the ecological role of roseobacters have 


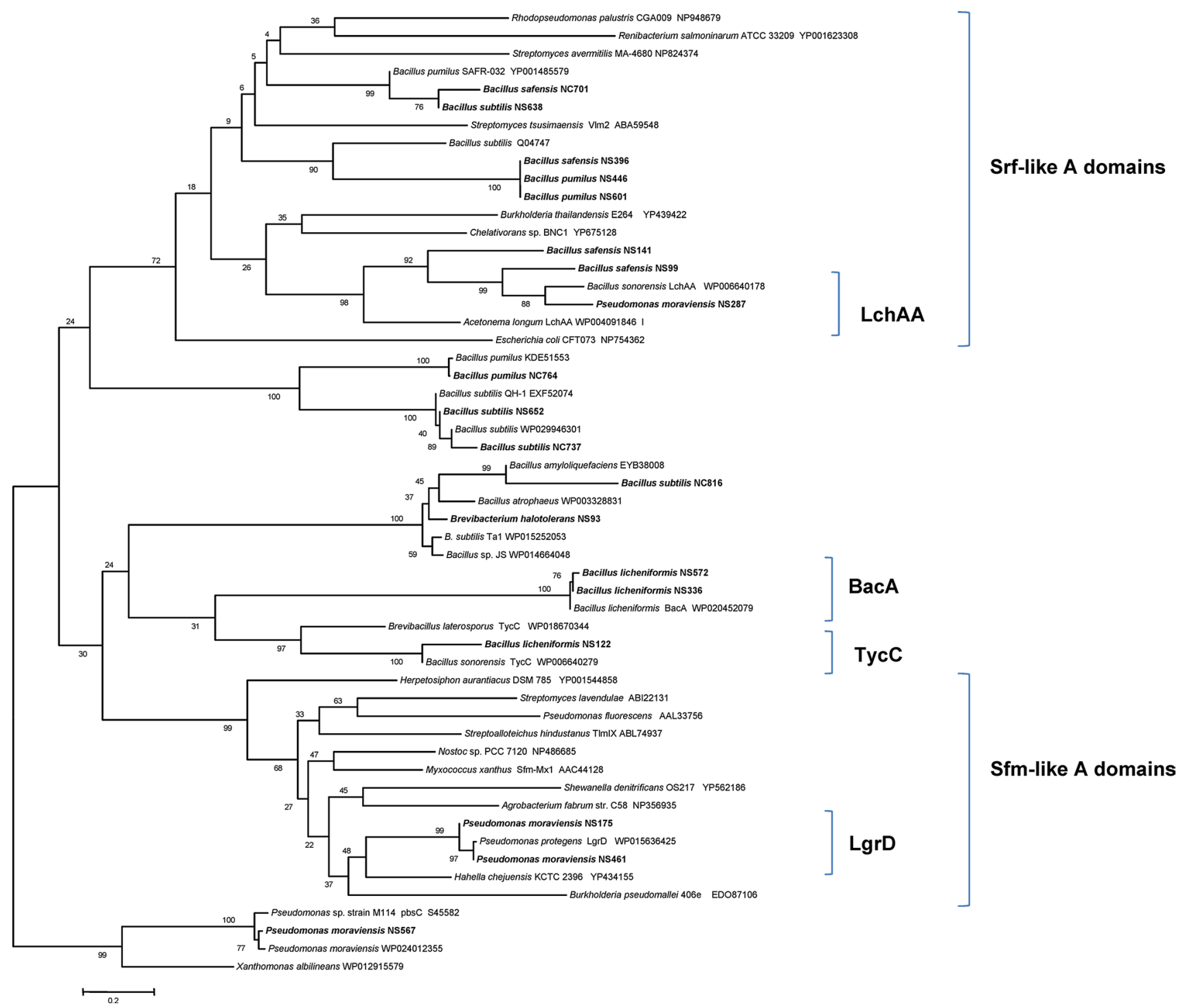

Fig. 4 Neighbor-joining phylogenetic tree from analysis of A domain amino acid sequences of Kolumbo most bioactive isolates (highlighted in bold type with NS for sediment and NC for chimney isolates) and reference sequences of known NRPS sequences including

demonstrated that they prevent surface colonization due to the production of secondary metabolites with antimicrobial activities against a variety of marine bacteria (Wagner-Dobler et al. 2004), pointing to a competitive advantage for these organisms. Particle-associated strains of the Roseobacter clade were demonstrated to be 10 times more likely to produce antimicrobial compounds than were free-living ones (Long and Azam 2001). Strain S453 is phylogenetically related to the genus Halomonas of the $\gamma$-Proteobacteria. Halomonas strains have been isolated from deep-sea volcanic weathered basalt and sulfide rocks in low-temperature hydrothermal vent fields and can oxidize $\mathrm{Fe}(\mathrm{II}), \mathrm{Mn}(\mathrm{II})$ as well as an extensive saframycin A and surfactin A families. Percentage bootstrap values of neighbor-joining analysis from 1,000 resamplings are indicated at nodes. The scale bar represents 0.5 AA substitutions per site

variety of organic compounds (Kaye and Baross 2000). Halomonas strain LOB-5 collected from Loihi Seamount (east of Hawaii, 1,174 m depth) produces the most hydrophilic of the reported amphiphilic peptidic siderophores, the loihichelins A-F (Homann et al. 2009). The rest of the most bioactive bacteria are affiliated with the genus Pseudomonas, which is considered among the important groups able to produce antibiotics. Strains of this genus have been also isolated from deep-sea environments since the 1960s (Quigley and Colwell 1968) at a variety of depths ( $\mathrm{Li}$ et al. 1999) including the West Pacific Ocean (>5,000-m depth) (Xu et al. 2007) and Mariana Trench, the deepest part of the ocean floor (Kato et al. 1997). 
Among various environmental niches, microbial communities at the limits of life include giant genes encoding multi-modular synthases, for the production of polyketides (PKSs) and nonribosomal peptides (NRPSs), two of the larger classes of marine microbial natural products exhibiting antimicrobial, antifungal and antiparasitic activities (Gulder and Moore 2009). The materialization of the information contained in such giant genes, commonly considered strain- or clone-specific properties (Fischbach and Walsh 2006), is associated with huge costs in terms of energy and time for the microbial producer, and this might explain their synthesis preferentially by nonpathogenic environmental bacteria with typically slow reproduction cycles to constitute weapons against predators and competitors for the same niche (Reva and Tummler 2008). According to our results and phylogenetic analyses, from the six isolates phylogenetically related to Bacillus group containing PKS genes, two were included in the NRPS/PKS group while four contained trans-AT PKS of type I genes in close relationship with previously isolated genes from South China Sea sponges (Zhang et al. 2008). trans-AT PKS assemblages derive from multiple recombinatorial events through horizontal recruitment of ketosynthase (KS) domains and display enzymatic features which do not fit to canonical architecture of cis-AT systems (Nguyen et al. 2008). They are mostly found in bacteria with unusual lifestyles and led to the discovery of novel polyketides with antibiotic (bacillaene, mupirocin and streptogramin) and antitumor (bryostatin) activities (Piel 2010). In addition, many pharmacologically important peptides derive from NRPS enzymology with remarkable structural diversity of natural products produced. This diversity depends on the different number of modules employed, the variety of activated amino acid substrates by A domains and the addition of modifying domains (Schwarzer et al. 2003). All the obtained adenylation domain gene sequences from Kolumbo isolates showed high similarity to NRPS A domains some of which are closely related to subunits of known peptides exhibiting antibiotic activity. Two aa sequences from Pseudomonas isolates matched with linear gramicidin $\mathrm{D}$, characterized by a relatively rare type of chain termination strategy by a reductase (R) domain (Du and Lou 2010). NRPS gene sequences deriving from three Bacillus isolates were closely related to bacitracin A and tyrocidine III synthases, which are released by diverse macrocyclization strategies, catalyzed by thioesterase (TE) domains (Kopp and Marahiel 2007). The majority of the A domains recovered from Bacillus isolates showed close similarity to B. subtilis surfactin domain. A Pseudomonas NRPS gene sequence was very close to Bacillus lichenysin A synthetase. Lipopetides surfactin and lichenysin exhibit antibacterial, antiviral and hemolytic activities (Rodriguez et al. 2006) by a detergent-like mechanism, which allows for modification of membrane permeability and solubilization. Surfactin suspends biofilm formation of other bacteria by preventing the attachment of the cells to surfaces (Roongsawang et al. 2011).

The high percentage of Kolumbo isolates exhibiting a wide antimicrobial activity as revealed by bioassays and detection of PKS and NRPS genes indicated a broad chemical diversity of biologically active metabolites. It seems that Kolumbo hydrothermal field provides an environment which hosts interesting bacteria with important characteristics like the production of bioactive natural compounds, and it warrants further exploration. The potential for discovery of novel bioactive molecules with activity against fungal and bacterial pathogens is evident.

Acknowledgments We thank Prof. Steven Carey and Dr. Katherine L. Croff Bell (Chief Scientist) for inviting us to participate in the $E / V$ Nautilus 2010 expedition, the crew of E/V Nautilus and the pilots of the remotely operated vehicle Hercules for their help in obtaining the samples. We also thank the members of Microbiology Group Prof. George Dialinas, Dr. Alexandros Savvidis and Dr. Sotiris Amillis for their precious help. This research has been co-financed by the European Union (European Social Fund-ESF) and Greek national funds through the Operational Program "Education and Lifelong Learning" of the National Strategic Reference Framework (NSRF)—Research Funding Program: Heracleitus II.

\section{References}

Austin B (1988) Marine microbiology. Cambridge University Press, New York

Blunt JW, Copp BR, Keyzers RA, Munro MHG, Prinsep MR (2014) Marine natural products. Nat Prod Rep 31:160-258

Carey S, Croff Bell KL, Nomikou P, Vougioukalakis G, Roman CN, Cantner K, Bejelou K, Bourbouli M, Fero Martin J (2011) Exploration of the Kolumbo rift zone. In: Bell KLC, Fuller SA (eds) New frontiers in ocean exploration: the E/V Nautilus 2010 Field Season, Oceanography, Supplement, vol 24, pp 24-25

Castro da Silva MA, Cavalett A, Spinner A, Rosa DC, Jasper RB, Quecine MC, Bonatelli ML, Pizzirani-Kleiner A, Corção G, Oliveira de Souza Lima A, Lima A (2013) Phylogenetic identification of marine bacteria isolated from deep-sea sediments of the eastern South Atlantic Ocean. Springerplus 2:127-137

Cottrell MT, Kirchman DL (2000) Community composition of marine bacterioplankton determined by $16 \mathrm{~S}$ rRNA gene clone libraries and fluorescence in situ hybridization. Appl Environ Microbiol 66:5116-5122

Devereux R, Wilkinson S (2004) Identification and classification of microbes using DNA and RNA sequences. In: Kowalchuk GA, de Bruijn FJ, Head IM, Akkermans AD, van Elsas JD (eds) Molecular microbial ecology manual. Kluwer Academic Publishers, the Netherlands, pp 509-850

Dick GJ, Lee YE, Tebo BM (2006) Manganese (II)-oxidizing Bacillus Spores in Guaymas Basin hydrothermal sediments and plumes. Appl Environ Microbiol 72:3184-3190

Du L, Lou L (2010) PKS and NRPS release mechanisms: review. Nat Prod Rep 27:255-278

Fickers P (2012) Antibiotic compounds from Bacillus: why are they so amazing? Am J Biochem Biotechnol 8:40-46 
Fischbach MA, Walsh CT (2006) Assembly-line enzymology for polyketide and nonribosomal peptide antibiotics: logic, machinery, and mechanisms. Chem Rev 106:3468-3496

Fischbach MA, Walsh CT (2009) Antibiotics for emerging pathogens. Science 325:1089-1093

Gärtner A, Blumel M, Wiese J, Imhoff JF (2011) Isolation and characterization of bacteria from the Eastern Mediterranean deep sea. A van Leeuw J Microb 100:421-435

Gerwick WH, Fenner AM (2013) Drug discovery from marine microbes. Microb Ecol 65:800-806

Gontang EA, Fenical W, Jensen PR (2007) Phylogenetic diversity of Gram-positive bacteria cultured from marine sediments. Appl Environ Microbiol 73:3272-3282

Gulder TAM, Moore BS (2009) Chasing the treasures of the sea-bacterial marine natural products. Curr Opin Microbiol 12:252-260

Homann VV, Sandy M, Tincu JA, Templeton AS, Tebo BM, Butler AJ (2009) Loihechelins A-F, a suite of amphiphilic siderophores produced by the marine bacterium Halomonas LOB-5. J Nat Prod 72:884-888

Inagaki F, Suzuki M, Takai K, Oida H, Sakamoto T, Aoki K, Nealson KH, Horikoshi K (2003) Microbial communities associated with geological horizons in coastal subseafloor sediments from the Sea of Okhotsk. Appl Environ Microbiol 9:7224-7235

Joint I, Muhling M, Querellou J (2010) Culturing marine bacteria: an essential prerequisite for biodiscovery. Microb Biotechnol 3:564-575

Kato C, Li L, Tamaoka J, Horikoshi K (1997) Molecular analyses of the sediment of the 11,000-m deep Mariana Trench. Extremophiles 1:17-23

Kaye JZ, Baross JA (2000) High incidence of halotolerant bacteria in Pacific hydrothermal-vent and pelagic environments. FEMS Microbiol Ecol 32:249-260

Kilias SP, Nomikou P, Papanikolaou D, Polymenakou PN, Godelitsas A, Argyraki A, Carey S, Gamaletsos P, Mertzimekis TJ, Stathopoulou E, Goettlicher J, Steininger R, Betzelou K, Livanos I, Christakis C, Bell KC, Scoullos M (2013) New insights into hydrothermal vent processes in the unique shallow-submarine arc-volcano, Kolumbo (Santorini), Greece. Nat Sci Rep 3:2421

Kontro M, Lignell U, Hirvonen M-R, Nevalainen A (2005) pH effects on 10 Streptomyces spp. growth and sporulation depend on nutrients. Lett Appl Microbiol 41:32-38

Kopp F, Marahiel MA (2007) Macrocyclization strategies in polyketide and nonribosomal peptide biosynthesis: review. Nat Prod Rep 24:735-749

Laatsch H (2006) Marine bacterial metabolites. In: Proksch P, Müller WEG (eds) Frontiers in marine biotechnology. Horizon Bioscience, Norfolk, pp 225-288

Li L, Kato C, Horikoshi K (1999) Bacterial diversity in deep-sea sediments from different depths. Biodivers Conserv 8:659-677

Liu Y, Lai Q, Dong Ch, Sun F, Wang L, Li G, Shao Z (2013) Phylogenetic diversity of the Bacillus pumilus group and the marine ecotype revealed by multilocus sequence analysis. PLoS One 8:e80097

Long RA, Azam F (2001) Antagonistic interactions among marine pelagic bacteria. Appl Environ Microbiol 67:4975-4983

Matz C, Webb JS, Schupp PJ, Phang SY, Penesyan A, Egan S (2008) Marine biofilm bacteria evade eukaryotic predation by targeted chemical defense. PLoS One 3:e2744

Mayer AMS, Rodríguez AD, Taglialatela-Scafati O, Fusetani N (2013) Marine pharmacology 2009-2011: marine compounds with antibacterial, antidiabetic, antifungal, anti-inflammatory, antiprotozoal, antituberculosis and antiviral activities; affecting the immune and nervous systems, and other miscellaneous mechanisms of action. Mar Drugs 11:2510-2573

Mohandass C, Rajasabapathy R, Ravindran C, Colaco A, Santos RS, Meena RM (2012) Bacterial diversity and their adaptations in the shallow water hydrothermal vent at D. João de Castro Seamount (DJCS), Azores, Portugal. Cah Biol Mar 53:65-76

Moore E, Arnscheidt A, Kruger A, Strompl C, Mau M (2004) Simplified protocols for the preparation of genomic DNA from bacterial cultures. In: Kowalchuk GA, de Bruijn FJ, Head IM, Akkermans $\mathrm{AD}$, van Elsas JD (eds) Molecular microbial ecology manual, 2nd edn. Kluwer Academic Publishers, the Netherlands, pp 3-18

Newman DJ, Cragg GM (2007) Natural products as sources of new drugs over the last 25 years. J Nat Prod 70:461-477

Nguyen TA, Ishida K, Jenke-Kodama H, Dittmann E, Gurgui C, Hochmuth T, Taudien S, Platzer M, Hertweck C, Piel J (2008) Exploiting the mosaic structure of trans-acyltransferase polyketide synthases for natural product discovery and pathway dissection. Nat Biotechnol 26:225-233

Nithya Ch, Pandian ShK (2010) Isolation of heterotrophic bacteria from Palk Bay sediments showing heavy metal tolerance and antibiotic production. Microbiol Res 165:578-593

Olins HC, Rogers DR, Frank KL, Vidoudez C, Girguis PR (2013) Assessing the influence of physical, geochemical and biological factors on anaerobic microbial primary productivity within hydrothermal vent chimneys. Geobiology 11:279-293

Pathom-aree W, Stach JEM, Ward AC, Horikoshi K, Bull AT, Goodfellow M (2006) Diversity of actinomycetes isolated from challenger deep sediment $(10,898 \mathrm{~m})$ from the Mariana Trench. Extremophiles 56:181-189

Penesyan A, Marshall-Jones Z, Holmstrom C, Kjelleberg S, Egan S (2009) Antimicrobial activity observed among cultured marine epiphytic bacteria reflects their potential as a source of new drugs. FEMS Microbiol Ecol 69:113-124

Penesyan A, Kjelleberg S, Egan S (2010) Development of novel drugs from marine surface associated microorganisms. Mar Drugs $8: 438-459$

Pettit RK (2011) Culturability and secondary metabolite diversity of extreme microbes: expanding contribution of deep-sea and deepsea vent microbes to natural product discovery. Mar Biotechnol $13: 1-11$

Piel J (2010) Biosynthesis of polyketides by trans-AT polyketide synthases. Nat Prod Rep 27:996-1047

Prieur D (2005) Microbiology of deep-sea hydrothermal vents: lessons for Mars exploration. In: Tokano T (ed) Water on mars and life. Springer, Berlin, pp 299-324

Quigley MM, Colwell JRR (1968) Properties of bacteria isolated from deep-sea sediments. J Bacteriol 95:211-220

Rademaker JLW, Louws FJ, Versalovic J, de Bruijn FJ (2004) Characterization of the diversity of ecologically important microbes by rep-PCR genomic fingerprinting. In: Kowalchuck GA, de Bruijn FG, Head IM, Akkermans AD, van Elsas JD (eds) Molecular microbial ecology manual, 2nd edn. Kluwer Academic Publishers, Dordrecht, pp 1-33

Reva O, Tummler B (2008) Think big-giant genes in bacteria. Environ Microbiol 10:768-777

Rodriguez L, Banat IM, Teixeira J, Rosario O (2006) Biosurfactants: potential applications in medicine. $\mathrm{J}$ Antimicrob Chemother 57:609-618

Roongsawang N, Washio K, Morikawa M (2011) Diversity of nonribosomal peptide synthetases involved in the biosynthesis of lipopeptide biosurfactants. Int J Mol Sci 12:141-172

Schwarzer D, Finking R, Marahiel MA (2003) Nonribosomal peptides: from genes to products. Nat Prod Rep 20:275-287

Senni K, Gueniche F, Changotade S, Septier D, Sinquin C, Ratiskol J, Lutomski D, Godeau G, Guezennec J, Colliec-Jouault S (2013) Unusual glycosaminoglycans from a deep sea hydrothermal bacterium improve fibrillar collagen structuring and fibroblast activities in engineered connective tissues. Mar Drugs 11:1351-1369

Skropeta D (2008) Deep-sea natural products. Nat Prod Rep 25:1131-1166 
Sogin ML, Morrison HG, Huber JA, Welch DM, Huse SM, Neal PR, Arrieta JM, Herndl GJ (2006) Microbial diversity in the deep sea and the underexplored "rare biosphere". PNAS 103:12115-12120

Stein T (2005) Bacillus subtilis antibiotics: structures, syntheses and specific functions. Mol Microbiol 56:845-857

Tamura K, Stecher G, Peterson D, Filipski A, Kumar S (2013) Mega 6: molecular evolutionary genetics analysis using maximum likelihood, evolutionary distance, and maximum parsimony methods, version 6.0. Mol Biol Evol 30:2725-2729

Tarasov VG, Gebruk AV, Mironov AN, Moskalev LI (2005) Deep-sea and shallow-water hydrothermal vent communities: two different phenomena? Chem Geol 224:5-39

Thornburg CC, Zabriskie TM, McPhail KL (2010) Deep-sea hydrothermal vents: potential hot spots for natural products discovery? J Nat Prod 73:489-499

Van Dover CL, German CR, Speer KG, Parson LM, Vrijenhoek RC (2002) Evolution and biogeography of deep-sea vent and seep invertebrates. Science 295:1253-1257

Wagner-Dobler I, Rheims H, Felske A, El-Ghezal A, Flade-Schroder D, Laatsch H, Lang S, Pukall R, Tindall BJ (2004) Oceanibulbus indolifex gen. nov., sp. nov., a North Sea alpha proteobacterium that produces bioactive metabolites. Int J Syst Evol Microbiol 54:1177-1184

Wilson ZE, Brimble MA (2009) Molecules derived from the extremes of life. Nat Prod Rep 26:44-71

Xu M, Miao L, Li X-C, Xiao X, Qian P-Y (2007) Antibacterial and antilarval activity of deep-sea bacteria from sediments of the West Pacific Ocean. Biofouling 23:131-137

Zhang W, Zhang F, Li Z, Miao X, Meng Q, Zhang X (2008) Investigation of bacteria with polyketide synthase genes and antimicrobial activity isolated from South China Sea sponges. J Appl Microbiol 107:567-575

Zhang W, Li Z, Miao X, Zhang F (2009) The screening of antimicrobial bacteria with diverse novel nonribosomal peptide synthetase (NRPS) genes from South China Sea sponges. Mar Biotechnol 11:346-355

Zheng L, Han XT, Chen HM, Lin W, Yan XJ (2005) Marine bacteria associated with marine macroorganisms: the potential antimicrobial resources. Ann Microbiol 55:119-124 